\section{Hope for new telescopes as Mauna Kea plan approved}

Hawaiian officials have conditionally approved a comprehensive management plan for the volcanic peak of Mauna Kea, which researchers hope will pave the way for the construction of more telescopes atop the 4,200-metre summit. The University of Hawaii has a long-term lease on a 46-square-kilometre preserve, of which 2 square kilometres are used by 13 observatories.

Some native groups believe that the terrain is sacred and oppose its development. In 2006, a judge reversed a permit for additions to the twin 10-metre Keck telescopes, saying that a summit-wide plan was needed.

The management plan, approved on 9 April by the state's Board of Land and Natural Resources, outlines the role of a management authority set up by the university. Some telescopes previously proposed for the site have been cancelled, but two major projects - the Thirty Meter Telescope and Pan-STARRS, the Panoramic Survey Telescope and Rapid Response System - are pushing ahead.

\section{AMERICA'S SCIENCE ADVISER SPEAKS}

John Holdren, US President Barack Obama's science adviser, talks to Nature.

On access to Obama:

'I don't have to ask anybody's permission to see the president, except the president."

On cap-and-trade costs:

"The actual numbers are far from devastating. If we had a price of $\$ 100$ a ton on carbon, the effect on a gallon of gasoline would be about 30 cents. We all know that the price of gasoline goes up and down by more than that in a week."

On climate legislation:

"If we go to Copenhagen without a climate policy in place, the freedom of our negotiators to negotiate anything meaningful is very limited."

On nuclear proliferation:

“I think we ultimately ought to put all uranium enrichment and fuel reprocessing, if any is done, under multinational control."

Read the full interview at

http://tinyurl.com/dk9w69.

\title{
Capture of wild jaguar raises eyebrows
}

A federal investigation is scrutinizing the capture and death of the only identified wild jaguar in the United States.

The animal, known as Macho B (right), was caught on 18 February by a biologist team from the Arizona Game and Fish Department and the private Borderlands Jaguar Detection Project (BJDP).

Released with a radio collar, the jaguar became ill, and was then recaptured and killed on 2 March.

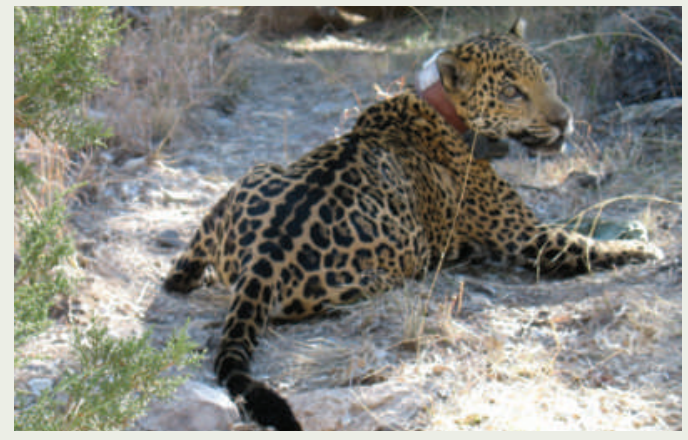

The biologists claim that the capture was inadvertent. But an inquiry by the US Fish and Wildlife Service, which monitors such endangered species, began last week after team tracker Janay Brun disclosed that BJDP biologist Emil McCain had directed her to bait a snare with scat from a female jaguar, suggesting that the jaguar was specifically targeted.

\section{Genome Canada cancels stem-cell project funding}

Genome Canada, a not-for-profit organization, has pulled its support for an international stem-cell consortium.

The International Regulome Consortium, which involves 12 countries and aims to understand the regulatory networks that guide cell behaviour, expected Genome Canada to provide Can \$20 million (US\$16 million) over 5 years towards the Can $\$ 80$-million project.

Genome Canada's head Martin Godbout says that the organization decided not to continue its support after an interim review of the project's science, management and budget recommended substantial changes. The consortium head, Michael Rudnicki, says that the decision was made because the organization lacked the funds after receiving no money in Canada's 2009 federal budget (see Nature 457, 646; 2009).

"This is about the conservative government failing to support science," he says. Rudnicki says he is working to organize funding and revamp the structure so that the consortium can continue.

\section{Argentina's dengue-fever outbreak reaches capital}

A resurgence of dengue fever in Latin America has hit Buenos Aires. On 9 April the city confirmed that the number of cases had exceeded 150.

Argentina is in the middle of its worst dengue epidemic since records began almost a century ago. Nationwide, more than 10,000 cases have been confirmed and specialists estimate a true total of about 30,000 . The country is also dealing with its first reported cases of the potentially lethal haemorrhagic form of the disease. Neighbouring Bolivia has been hit by as many as 114,000 dengue cases this year.

Dengue has become the world's most widely spread vector-borne disease over the past decade, according to Ricardo Gürtler, a dengue researcher at the University of Buenos Aires. Largely driven out of Latin America in the 1950s and 1960s, dengue's comeback has been linked to factors such as climate change, urbanization - which has been particularly rapid in Latin America and decreased use of pesticides that reliably kill the mosquito vector.

\section{Japanese stimulus provides green boost}

Japan's Prime Minister Taro Aso has announced a ¥15.4-trillion (US\$154billion) stimulus package that includes measures to spur on the country's greentechnology industry.

The package, announced on 10 April, allocates $¥ 1.6$ trillion to low-carbon technologies, including plans to equip schools and homes with solar panels to increase solar-energy capacity 20 -fold to 280 gigawatts by 2020 . Subsidies in the range of $¥ 250,000$ for electric and hybrid cars aim to create sales of 1 million environmentally friendly cars by the same deadline.

Aso is pitching the project - which still needs parliamentary approval - as a bridge to a future in which Japan is less dependent on cars and conventional electronics manufacturing and thrives on environmental technologies.

A supplementary budget including the green stimulus will be submitted to parliament on 27 April.

\section{Correction}

In 'Open-access policy flourishes at NIH' (Nature 458, 690; 2009), the number of articles downloaded from PubMed Central represent the average usage on a typical weekday, not a monthly total as we stated. 